\title{
REVIEW OF NEW AMERICAN STUDIES ON THE CIVIL WAR (1861-1865) AND RECONSTRUCTION IN THE USA (1865-1877) FOR 2019
}

\author{
Ilya A. Sokov \\ Volgograd State University, Volgograd, Russian Federation
}

\begin{abstract}
Introduction. Studies of American historians on the Civil War and Reconstruction continue to be central issues in the $21^{\text {st }}$ century. There is an increased public demand for these studies. The author of the analytical review of American publications tries to answer the question of what this interest is related to. Methods. The author of the review uses the methodological tools such as the scientific principle of objectivity, the special historicalcomparative method and the systematic approach to answer this question. Analysis. The author points out the main areas of studying new aspects marked by American historians of the mid- $19^{\text {th }}$ century. These areas include the issues and interpretations on military, political, everyday, anthropological, social and cultural, and economic history. Besides, new approaches in peer-reviewed monographs for the comprehensive coverage of the study material of this issue are highlighted. Results. The interest of academicians and the American public to studying the historical period of the Civil War and Reconstruction, on the one hand, tells about carrying the deep psycho-civilizational trauma by all subsequent generations of both white and black Americans at this time, and on the other hand, this war debunks the myth of God's chosen destiny of the American nation to build a "City on a Hill". Constant refinements, additions, revisions, and reinterpretations of the events and consequences of the Civil War and Reconstruction in contemporary American historiography only confirm this conclusion. The publications selected by the reviewer on this issue for 2019 not only introduce new American historical works to Russian Americanists, but also provide an opportunity to expand their own research on this issue.
\end{abstract}

Key words: Civil War, Reconstruction, slavery, emancipation, segregation, civil rights.

Citation. Sokov I.A. Review of New American Studies on the Civil War (1861-1865) and Reconstruction in the USA (1865-1877) for 2019. Vestnik Volgogradskogo gosudarstvennogo universiteta. Seriya 4. Istoriya. Regionovedenie. Mezhdunarodnye otnosheniya [Science Journal of Volgograd State University. History. Area Studies. International Relations], 2020, vol. 25, no. 3, pp. 225-239. (in Russian). DOI: https://doi.org/10.15688/ jvolsu4.2020.3.20

\section{ОБЗОР НОВЫХ АМЕРИКАНСКИХ ИССЛЕДОВАНИЙ ЗА 2019 Г. ПО ТЕМЕ ГРАЖДАНСКОЙ ВОЙНЫ (1861-1865 гГ.) И РЕКОНСТРУКЦИИ В США (1865-1877 гг.)}

\section{Илья Анатольевич Соков}

Волгоградский государственный университет, г. Волгоград, Российская Федерация

\footnotetext{
Аннотация. Введение. Исследования американских историков по тематике Гражданской войны и Реконструкции продолжают оставаться центральными в XXI веке. Причиной тому является повышенный общественный запрос на эти исследования в США. В представленном аналитическом обзоре американских публикаций автор пытается ответить на вопрос, с чем связан данный интерес. Meтодbl. В статье использовались такие методологические инструменты, как научный принцип объективности, специальный историковнительный метод и системный подход. Анализ. При анализе были выделены основные направления изучения новых аспектов американскими историками периода середины XIX века. В их число входят исследования по военной, политической, повседневной, антропологической, социальной и культурной, а также экономической истории. Кроме того, автор выделил в рецензируемых монографиях новые подходы к изуче-
} 
нию материала указанной тематики для его всестороннего охвата. Результаты. Неснижаемый интерес академической и американской общественности к исследованиям исторического периода Гражданской войны и Реконструкции, с одной стороны, говорит о глубокой психоцивилизационной травме, полученной в это время и наблюдающейся у всех последующих поколений как белых, так и темнокожих американцев, а с другой - развенчивает миф о богоизбранном предназначении американской нации для построения «града на холме». Постоянные уточнения, дополнения, ревизии и переосмысление событий и последствий Гражданской войны и Реконструкции в современной американской историографии только подтверждают этот вывод. Выбранные рецензентом публикации по указанной тематике за 2019 г. не только знакомят российских американистов с новыми американскими историческими работами, но и дают возможность расширить собственные исследования по этой тематике.

Ключевые слова: Гражданская война, Реконструкция, рабство, эмансипация, сегрегация, гражданские права.

Цитирование. Соков И. А. Обзор новых американских исследований за 2019 г. по теме Гражданской войны (1861-1865 гг.) и Реконструкции в США (1865-1877 гг.) // Вестник Волгоградского государственного университета. Серия 4, История. Регионоведение. Международные отношения. - 2020. - Т. 25, № 3. - С. 225239. -DOI: https://doi.org/10.15688/jvolsu4.2020.3.20

Введение. Центральным событием в истории США ХIX в. считается Гражданская война с последующей Реконструкцией. В течение последующих 150 лет историки Соединенных Штатов тщательно и всесторонне изучали различные аспекты этого социального явления, создали множество концепций и теорий, объясняющих один из самых сложных этапов развития американского общества. Размах этих исследований не сокращается и в XXI веке. Достаточно сказать, что за период празднования 150-летия упомянутого события (2015-2016 гг.) только в США было опубликовано по теме Гражданской войны 507 монографий, 1794 статьи в академических журналах, 1603 статьи в периодических журналах, 8159 статей в газетах, а за прошлый 2019 г. - 136 монографий, 273 статьи в академических журналах и 377 статей в периодических журналах, 1771 газетная статья [11].

Сравнивая эти цифры, можно отметить, что в американском социуме есть определенный общественный запрос на продолжение исследований по тематике Гражданской войны и Реконструкции. С одной стороны, в Соединенных Штатах ежегодно публикуется огромное количество материала по этой теме, с другой - сделать обзор всей этой опубликованной продукции практически невозможно. В связи с этим в своем исследовании мы выделили полтора десятка монографий, которые, на наш взгляд, отражают практически все направления современных исследований.

Методы. В данной статье был использован научный принцип объективности, позво- ливший из имеющегося массива библиографических сведений о публикации научных работ в США за 2019 г. выделить несколько направлений, посредством которых в чем-то по-новому рассматриваются события Гражданской войны и Реконструкции. С помощью специального историко-сравнительного метода в каждом направлении выделены характерные работы, отражающие их специфику. Применение системного подхода позволило выделить основные проблемы, над которыми работают американские ученые, и понять, в каком направлении эти исследования смогут продолжаться.

Анализ. Изучение американских публикаций по теме Гражданской войны и Реконструкции за 2019 г. дает основание говорить о разных направлениях и подходах в исследованиях американских историков этого периода.

Безусловно, главным направлением продолжает оставаться военная история. Примером исследований здесь может служить монография Ларри Дж. Даниэля «Побежденные: почему армия Теннесси потерпела неудачу» [6]. Работа состоит из 23 глав, в которых подробно описываются военные события, связанные с действиями армии Теннесси. Автор (по его словам) произвел ревизию устоявшихся представлений о причинах поражения армии конфедератов (как из-за несоответствующего лидерства, так и борьбы за влияние в ней среди генералов), взяв в качестве основного подхода рассмотрение армии как специфического института, действующего функционально по-разному в военное и мирное вре- 
мя [6, p. хі]. Не отрицая роль военных личностей в поражении армии Теннесси, Л. Даниэль обращает внимание на фактор секционализма, который выражался в местничестве разных областей штата, производящих различную сельхозпродукцию, и тем самым сдерживал единство армии. К тому же проблема усугублялась из-за армейской политики президента Конфедерации Дж. Дэвиса, армейская политика которого делила все подразделения южной армии территориально с командующими и их собственными миссиями [6, p. 8]. В связи с этим к лету 1862 г. в армии Теннесси уже были отдельные подразделения из штатов Арканзас, Кентукки и Луизианы. Позднее она пополнилась подразделениями из горных областей Алабамы и Джорджии, которых остальные просто презирали как «людей выглядящих пригодными только для жизни в скалах» [6, p. 9].

Л. Даниэль считает, что если армия генерала Ли демонстрировала живучесть штатов Конфедерации, то армия Теннесси была ее противоположностью, «представляя непрочность Конфедерации» [6, xii].

Начало такому представлению положило формирование армии Теннесси под руководством губернатора Ишема Г. Харриса и окружение его неспособными бригадными генералами, которые назначались из администраторов либо ветеранов Мексиканской войны. Автор указывает, что из 135 чел., которым предстояло получить звание полковника в Теннесси, за исключением Эндрю Джексона III никто не учился в Вест-Пойнте, и только четверо окончили частные военные академии, а богатство и известность служили основой для назначения большинства теннессийских полковников, из которых было девять врачей и сорок юристов [6, p. 2-3].

Из 75000 единиц различного огнестрельного оружия только 4000 были годны к употреблению. Военные лагеря, где были собраны для обучения солдаты, каждый вечер посещали жены с детьми, а каждую ночь устраивались танцы с молодыми особами [6, p. 3]. К тому же вскоре в лагерях начались болезни, главным образом корь и диарея.

Другой важной особенностью отсутствия боеспособности армии Теннесси автор называет политический фактор. Жители более се- верного и не хлопкового пояса штата на выборах 1860 г. поддержали партию Конституционного Союза (Constitutional Union Party) и позже всех примкнули к Конфедерации. В связи с этим понятно, заключает автор, почему в феврале 1862 г. при падении форта Донельсон (Donelson) 1640 военнопленных дали клятву верности северянам [6, p. 6]. Большинство людей в армии Теннесси понимали, что они борются за интересы «горстки хлопковых плантаторов из Алабамы и Миссисипи» $[6$, p. 7].

Следующим фактором, приведшим к поражению армии, автор считает отсутствие единой стратегии по защите различных объектов по берегам рек Миссисипи и Теннесси. Так, генерал П.Дж.Т. Борегар считал, что конфедеративные подразделения должны быть мобильными, а генерал Л. Полк (Leonidas Polk), наоборот, придерживался мнения, что форты и города у рек представляют собой «Гибралтар Юга» и для поддержания их неприступности требуются значительные силы, чтобы выдержать длительную осаду. Такая же полемика была в штате Миссисипи годом позже между генералами Джоном К. Пембертоном и Джозефом Э. Джонстоном.

Кроме того, существовали и другие многочисленные факторы, такие как сокращение живой силы армии и уменьшение кавалерийского корпуса в результате боев, имелись материально-технические трудности и недостаток мобильности, деструктивные политические действия президента Джефферсона Дэвиca, слабая связь между различными конфедеративными штатами [6, p. хіi].

В противоположность Л. Даниэлю Д. Силкенет в монографии исследования военной истории «Поднятие белого флага: как капитуляция определила американскую Гражданскую войну» [13] утверждает, что в армиях Севера и Юга в течение войны происходили многочисленные капитуляции как тактического, так и стратегического характера, которые определялись предвоенной гражданской культурой и «выросли из унаследованных представлений о том, что капитуляция помогала отличить цивилизованную войну от варварства» $[13$, p. 3].

Автор проявляет интерес к исследованию процесса капитуляции как отдельных сол- 
дат, так и армий, а также к сдаче городов и гражданских лиц противоборствующими сторонами на всем протяжении Гражданской войны, что позволяет интерпретировать события не только военной, но социальной и культурной истории. По его мнению, взгляд на Гражданскую войну с точки зрения людей, сдавшихся в плен, открывает новые горизонты на знакомые темы, позволяя по-новому взглянуть на такие разнообразные проблемы, как тяжелое положение военнопленных, действия партизан Конфедерации, южан-юнионистов и афроамериканских солдат; понимание культуры чести; использование опыта боевых действий и следование законам войны $[13$, p. 4]. Автор уверен, что капитуляция глубоко повлияла как на характер, так и на исход Гражданской войны.

Д. Силкенет утверждает, что за время Гражданской войны каждый четвертый участник боев сдавался противнику и этот феномен отсутствовал в какой-либо американской войне до или после. При этом он ссылается на неполные статистические данные, говорящие о том, что более 673000 солдат сдались в плен во время Гражданской войны в США, включая по меньшей мере 211000 солдат Союза и 462000 солдат Конфедерации. Формальные капитуляции, такие как при Виксбурге, Аппоматтоксе и Беннетт-Плейсе, составили примерно половину этой цифры [13, p. 2].

Автор подчеркивает, что в американской Новейшей истории вообще не упоминаются факты капитуляции военнослужащих США во время боев и активно поддерживается военно-политический миф о непобедимости американцев. При этом он приводит слова покойного сенатора Дж. Маккейна, который говорил: «Мы - американцы, и мы никогда не сдадимся», хотя, как известно, он сам был во вьетнамском плену [13, p. 3].

Другой особенностью капитуляций во время Гражданской войны было отсутствие признаков позора или бесчестья. Более того, по мнению автора, майор Роберт Андерсон стал знаменитым национальным героем за свою капитуляцию в форте Самтер, который выдержал осаду федеральных войск в 1863 1865 годах. Для северян же это название ассоциировалось с расколом и предательством, а для южан-конфедератов стало символом со- противления и мужества. Авторитет Роберта Э. Ли также только вырос после капитуляции в здании суда графства Аппоматтокс. Приняв капитуляцию, генерал Улисс Грант положил конец Гражданской войне в США [13, p. 3].

Можно, конечно, предположить, что подобная история капитуляций была необычным явлением и она отражала особенности ведения «мягкой» войны без необходимости истребления собственного населения и «мягкого» отношения к капитулянтам. При этом автор утверждает, что наряду с цивилизационным порядком ведения войны присутствовал также варварский порядок. Он касался United States Colored Troops (далее - USCT). Цветные войска Соединенных Штатов были полками в армии США, состоящими в основном из афроамериканских солдат, хотя члены групп других меньшинств также служили в этих подразделениях, южных юнионистов и партизан (последние боролись в штатах Канзас, Миссури и Арканзас). Темнокожие солдаты Союза шли в бой, зная, что они не могут сдаться, потому что в плену их могут ждать казни, пытки или обращение в рабство [13, p. 297], и поэтому они шли под своим черным флагом, означавшим их борьбу против рабства и несправедливости. Как установлено, несмотря на проявление человечности в период Гражданской войны, по последним оценкам американских историков в ней погибло более 750000 чел. [13, p. 295].

Подобный нетрадиционный подход к исследованию военной истории Гражданской войны и Реконструкции в США использован в коллективной монографии «Гражданская война на Рио-Гранде, 1846-1876 гг.» под редакцией Розанны Бача-Гарза, Кристофера Л. Миллера и Рассела К. Сковронека [14]. Одиннадцать авторов, написавших свои эссе для этой книги, пересматривают общепринятый историками подход о том, что события в Техасе во время указанного периода носили периферийный характер и в малой степени влияли на общий ход Гражданской войны и Реконструкции в США. Свои доводы они обосновывают тем, что Гражданская война в Америке не проходила на едином фронте или в одном месте, а сражения велись в разное время и в различных штатах. То же касается и сроков ее проведения. «Ни один здравомыслящий 
историк не скажет, что эпоха Гражданской войны началась именно 12 апреля 1861 года с обстрела форта Самтер и что война закончилась росчерком пера 9 апреля 1865 года в здании суда графства Аппоматтокс» [14, p. хіii].

Для разных людей Америки окончание войны имело свои сроки. Так, в бывших штатах Конфедерации официальная военная оккупация и военное положение продолжались более десяти лет после капитуляции Роберта Э. Ли.

Если эти рассуждения редакторов о местах и времени Гражданской войны можно как-то принять, понимая, что они хотят выделить еще нераскрытые страницы Гражданской войны, то их утверждение, что в Техасе периодизация Гражданской войны должна быть принята в рамках 1846-1876 гг., не выдерживает критики. По мнению авторов, 1846 г. - начало войны с Мексикой и опыт американских офицеров и солдат в ней - дал им возможность осознанно участвовать в Гражданской войне на стороне конфедератов, а 1876 г. - это год укомплектования войск преобладающе афроамериканскими солдатами, которых первоначально именовали Цветные Войска Соединенных Штатов (USCT), более известные как солдаты Буффало. В последующем их отправили на Великие равнины для подавления восстания индейских племен. В связи с этим период 1846-1876 гг. кроме времени самой Гражданской войны, включает и другие события, которые к ней не относятся.

С помощью идеи американского историка Эллиота Уэста (Elliott West) [15] Реконструкция рассматривается в широком смысле как «Строительство» (Construction) и «Beликое объединение» (Great Consolidation), где пространственное приращение США в первой половине XIX в. считается одной из предпосылок ее наступления. Авторы монографии указывают совсем на другое понятие - «гражданская война», и тем самым вольно изменяют устоявшиеся исторические представления.

Между тем вполне можно согласиться с авторами эссе и с редакторами в том, что штат Техас, как и долина Рио-Гранде, все же отличались от американских штатов Севера и Юга в силу существования там мультикультурного общества, отсутствия института рабства (перед началом Гражданской вой- ны, как указано в монографии, на весь Техас приходилось не более шестидесяти рабов), разделения общества на тех, кто строил «подземную дорогу» для освобождения рабов, и тех, кто их ловил и возвращал хозяевам. Поэтому с наступлением Гражданской войны в штате Техас произошло разделение на сторонников Союза и Конфедерации. Эти предпосылки и дают основание авторам монографии считать, что военные события в Teхасе были особенными, непохожими на события в других штатах.

Продолжением исследования военной истории Гражданской войны в США является монография Филипа Джерарда «Последнее поле битвы: Гражданская война приходит в Северную Каролину» [8]. Эта монография состоит из сорока трех эссе, которые все связаны в военных и социальных аспектах Гражданской войны со штатом Северная Каролина, рассказаны самими участниками событий, которые не могли знать, как эти события продолжатся или закончатся. В связи с этим они написаны не в прошедшем, а в настоящем времени. По мнению автора, такой подход позволяет читателю сопереживать происходящему и, возможно, даже представить себя участником событий. Он указывает, что война превратилась в движущееся лоскутное одеяло речных сражений, стычек на горных перевалах, засад на пустынных проселочных дорогах, набегов на побережье, эпизодических сражений, секретных шпионских миссий, гарнизонных дежурств, работы для тюрем, больниц, железных дорог, тяжелого физического труда на фермах и фабриках и всего остального [8, p. хі].

В связи с этим нельзя не согласиться с Ф. Джерардом, что «каковы бы ни были великие политические причины войны, какие бы великие сражения ни решили ее исход, каким бы абстрактным это ни казалось нам полтора столетия спустя, величайшая истина, которую я знаю, такова: война (для участников. - И. С.) всегда была их личным делом» [8, p. хіi].

Направление исследований политической и экономической истории Гражданской войны и Реконструкции представлено монографией Джозефа П. Рейди «Иллюзии эмансипации: стремление к свободе и равенству в сумерках рабства» [12]. В своей работе ав- 
тор утверждает, что устоявшийся взгляд на то, что рабство в США было отменено одним актом или рядом актов (закон о Конфискации 1861 г., закон о Конфискации 1862 г., Предварительная и Заключительная Прокламация эмансипации от сентября 1862 г. и января 1863 г., Тринадцатая поправка к конституции США от 31 января 1865 г.) неточно, это был длительный и незаконченный по времени процесс, перешедший в сегрегацию. В подтверждение своих слов он ссылается на известного историка Гарварда Чарльза Харриса Уэсли, который говорил: «"Никто не может сказать, в какой день месяца или месяц года было отменено рабство в Соединенных Штатах"; скорее, “цепи рабства были постепенно ослаблены”» [12, p. 5].

Этот подход в уточнении исторической памяти развенчивает еще один устоявшийся миф, что порабощенные и свободные афроамериканцы были пассивными объектами действий других людей (например, президента А. Линкольна). На самом же деле они, как исторические акторы, сами способствовали своему освобождению.

Дж. Рейди уточняет, что даже к концу Гражданской войны люди всех политических убеждений признали роль темнокожих солдат в достижении победы, но общественное мнение по-прежнему было разделено относительно того, давала ли эта служба возможность на полное гражданство, включая право голосовать [12, p. 10].

По мнению автора, в XX в. историки согласились, что Реконструкция была неудачным экспериментом в «управлении неграми», для которых легальное санкционированное подчинение афроамериканцев было подходящим решением [12, p. 10].

При всем уважении к исследованию Дж. Рейди следует отметить, что введенные им категории (время, пространство и дом как местожительство) только затеняют объяснение «иллюзий эмансипации». На наш взгляд, введенный в научный оборот термин «формирующие события» канадским политологом Нельсоным Вайсмэном в 2007 г. для обозначения изменений, связанных с Американской революцией и Гражданской войной, более полно и адекватно объясняет особенности этих исторических процессов [16].
Вывод автора состоит в том, что эмансипация военного времени не стала полным политическим освобождением, не говоря уже о более тягостном экономическом положении, в котором бывшему рабу надо было брать ответственность за содержание семьи: искать не только работу, но жилище для себя и членов своей семьи. Государство не взяло на себя никаких социальных обязательств. Темнокожие вольноотпущенники не получили 40 акров земли, как они просили [12, p. 345], хотя по Гомстед-акту от 20 мая 1862 г. белые иммигранты получили право приобрести в собственность незанятые земли на западе страны. Это и понятно, северным капиталистическим штатам нужны были рабочие руки для фабрик и заводов.

Другим примером исследования экономической и культурной истории являются четвертая и пятая главы монографии Эндрю Хита «В Союзе существует сила: Филадельфия в эпоху городской консолидации» [9]. Направленность этой книги в большей степени следует отнести к городской истории Соединенных Штатов, которая убедительно доказывает, что урбанизация американских городов в середине XIX в. была вызвана бурным развитием капитализма и стала одной из объективных, но косвенных предпосылок наступления Гражданской войны и эмансипации темнокожего населения.

Автор считает, что Филадельфия между 1840-1870 гг., несмотря на отставание НьюЙорка в гонке за городское превосходство, по площади удваивалась каждые двадцать лет, а луга уступили место улицам, фабрикам и домам» $[9$, p. 4]. Закон о консолидации Филадельфии (Philadelphia's Consolidation Act of 1854) способствовал территориальному расширению города, его бурному промышленному и финансовому развитию и создал прецедент для других городов, таких как Нью-Йорк, которые также хотели расширить свои границы.

К началу Гражданской войны старая элита в Филадельфии сменилась на новую: ее основой стали бизнесмены и партийные боссы. Если «практическая консолидация» филадельфийцев перед началом Гражданской войны заключалась не только в расширении городского центра и объединении пригородов, но и в соблюдении гражданских прав и возобнов- 
лении политики экономического роста. С началом Гражданской войны «военная консолидация» поддерживалась четко организованной мобилизацией приграничного города с сепаратистскими штатами. Но не военные усилия беспокоили отцов города - рабство и местничество (групповщина) [sectionalism] раскалывали филадельфийское общество. «Торговцы связанные родственными узами и торговлей с Конфедерацией были в лучшем случае равнодушны к делу Союза» [9, p. 168].

Филадельфия как крупнейший американский центр железнодорожного строительства и промышленного производства, по мнению Э. Хита, безусловно, поддерживала Республиканскую партию, несмотря на то что муниципальные торговые и финансовые интересы были тесно связаны с южными штатами. По сути, рабство и война раскололи «богатейшую десятую часть общества» Филадельфии и угрожали свести на нет большую часть работы предыдущих пятнадцати лет по консолидации городского сообщества.

Отличительной особенностью военных лет стало создание в Филадельфии сначала юнионистских клубов, которые затем переросли в общественные Лиги. Члены Лиги не чурались политики, но, как и их предшественники в 1850-е гг., они верили, что объединенная буржуазия может оказывать влияние через свое положение. Как выразился один из основателей клуба, он предлагал «достичь национальной и политической цели социальными средствами» [9, р. 169-170].

Отдельно темнокожими в Филадельфии были созданы Пенсильванская Лига за равные права и Профсоюзная лига цветных людей, где «черный лоялизм подталкивал буржуазных филадельфийцев к более эгалитарной позиции по гражданским правам» [9, p. 171].

По истечении нескольких месяцев после окончания военного конфликта Филадельфия не смогла консолидировать республиканскую гражданскую культуру, провозглашенную во время Гражданской войны, и эмансипация афроамериканцев уступила место их сегрегации. Даже завоеванные права афроамериканцев в Филадельфии перед Гражданской войной на совместный проезд с белыми были в конце концов отменены, хотя город в период Реконструкции претендовал на звание «Столицы рабочих».

Одно из важных направлений исследования - это истории повседневности времен Гражданской войны. Так, в монографии доцента университета Лойолы Нового Орлеана Джеймса Г. Мендеза «Великая жертва: черные солдаты-северяне, их семьи и опыт Гражданской войны» [10] на основе документов Национального архива (Вашингтон) автором исследуется положение негритянских семей, главы которых были солдатами и воевали во время Гражданской войны на стороне северян. Он указывает, что эти семьи испытывали нужду, так как чернокожие солдаты в большинстве своем за службу не получали денежное довольствие (или получали значительно меньше чем белые солдаты) и поэтому не могли помочь своим детям и женам. Они воевали в надежде на получение лучшей жизни после войны и отмены рабства, хотя испытывали порой от белых солдат и офицеров унижения. В монографии исследуется история черных солдат-северян от начала Гражданской войны до начала 1866 г., когда последний полк черных-северян вернулся домой. Автор подчеркивает, что «эта работа отводит главное место жертвам, которые испытали семьи черных-северян, а также черные солдаты, чтобы добыть победу для Союза» [10, p. 2].

Особое внимание автор обращает на то обстоятельство, что семьи афроамериканцев на Севере находились в более тяжелом положении в силу того, что главы семей не получали армейское довольствие и не могли им поделиться с семьей; жены солдат, имея на попечении детей, не могли найти работу; сами семьи были небольшими и состояли как правило, из родителей и их детей.

В войсках из-за враждебности белых солдат были сформированы отдельные «черные полки», которые во время боя шли впереди, а после него располагались отдельно от белых подразделений. К тому же они не имели шанса сдаться, чтобы не быть повешенными как мятежники, либо их могли обратить снова в рабство.

Враждебность к афроамериканцам проявлялась и среди гражданского населения. Ярким примером может служить бунт в НьюЙорке из-за призыва (New York City draft riots) 
в 1863 г., где протесты начались как следствие недовольства призывом, а переросли в расовый погром, жертвами которого стали ни в чем неповинные чернокожие [10, p. 4].

В рецензируемой монографии Дж. Мендез использовал многочисленные письма темнокожих женщин, которые сохранились в Национальном архиве. По его словам, последние являются наиболее ценными из источников, использованных в этом исследовании. «Хотя большинство писем составляют не более одной страницы, они важны, поскольку представляют собой единственные письменные первоисточники и записи, оставленные афроамериканскими женщинами в период Гражданской войны» [10, p. 5-6].

Кроме того, эти письма показывают первый опыт проявления гражданственности со стороны темнокожих женщин. Направляя свои письма американскому правительству, они надеялись на проявление гражданского равенства со стороны чиновников и компенсации за вклад их мужей в восстановление Союза.

В монографии автором вводится специальный термин - «северные афроамериканцы» (northern blacks), то есть те афроамериканцы, которые либо никогда не были в рабстве, либо беглые из рабства на север страны люди. Автор уточняет, что северные афроамериканцы пошли на войну по причинам, во многих отношениях сильно отличавшихся от причин их собратьев на юге, которым нужно было победить рабство, чтобы получить свою свободу навсегда или свободу для членов своей семьи, которые все еще находились в рабстве.

Северные афроамериканцы хотели, прежде всего, получить общественное признание, через их участие в войне с конфедератами, несмотря даже на то, что условия прохождения военной службы для них были более тяжелыми, а денежное довольствие меньше, чем у белых солдат, а порой они воевали и без получения денежного довольствия.

«Это различие важно понять для того, чтобы оценить сложности и жертвы, принесенные черными северянами, когда они решили поддержать Союз» [10, p. 10].

По оценке американских исследователей, книга «Великая жертва» дает «новый взгляд на жизнь афроамериканских мужчин и женщин с севера в период Гражданской войны. Данная книга вносит важный вклад в литературу о Гражданской войне в целом, а также в литературу об афроамериканцах в эпоху Гражданской войны и в северном тылу» [10, p. 12].

К этому же направлению истории повседневности относится коллективная монография «Афроамериканцы в центральной истории Техаса: от рабства к гражданским правам» под редакцией Брюса А. Гласрада, Деборы М. Лайлс [1]. Из 16 глав работы, охватывающей период исследования почти ста лет с середины XIX в., пять первых глав первой части монографии затрагивают период Гражданской войны и Реконструкции. В данной монографии собраны эссе по исследованиям американских историков за последние десятилетия, объединенные одним посылом, состоящим в изложении особенностей рабства в пограничном районе, каким на то время являлся Техас.

Так, в эссе Деборы Лайлс «Домашний скот и рабство в Северном Центральном Техасе. Взгляд из округа Стивенс» [1, р. 23-40], автор полемизирует с известным американским историком Рэндолфом Б. Кэмпбеллом (автором труда «Империя для рабства: специфичность института в Техасе, 1821-1865 гг.» [3], подготовленного им тридцать лет тому назад), который считал, что рабство в Техасе в середине XIX в. в силу большего распространения животноводства, чем растениеводства, «было бы невыгодно и поэтому вымерло бы естественным путем как только оно переместилось бы на запад от Кросс Тимберс» [1, p. 24].

Д. Лайлс на основе архивных статистических данных опровергает этот аргумент Р. Кэмпбелла, указывая, что скотоводы, имевшие немногочисленных рабов, были более успешны в производстве и торговле скотом и получали наибольшую прибыль. Кроме того, исторические интерпретации Кэмпбелла, по мысли Д. Лайс, «искажают многообразие рабства» в США перед Гражданской войной [1, p. 35].

В следующем эссе Уильяма Дина Карригэна «Рабство на границе. Специфический институт в Центральном Техасе» [1, p. 41-69] автор спорит с историком Р. Кэмпбеллом, ут- 
верждавшим, что рабство «в штате Техас ничем принципиально не отличалось от института рабства, существовавшего в других уголках Соединенных Штатов» [1, p. 42].

Аргументы У. Карригэна заключаются в том, что рабство в Техасе существенным образом отличалось от других южных штатов, потому что это был пограничный район, где раб мог убежать к дружелюбным индейцам или через границу в Мексику. В этом пограничном районе как нигде сосуществовали четыре культуры поселенцев: англоязычных переселенцев, беглых рабов из южных штатов, индейских племен и мексиканцев, которые конкурировали между собой за получение определенных преимуществ. Соперничество этих культур способствовало, по мнению автора, тому, что «эти четыре культуры Техаса оставались втянутыми во множество кровавых конфликтов на протяжении всего девятнадцатого века» $[1, \mathrm{p} .42]$.

Условия пограничной области накладывали определенные особенности на рабовладение. По мнению У. Карригэна, перед началом Гражданской войны рабы Техаса имели больше привилегий, чем в других штатах, и, что более важно, по отношению к ним проявлялся определенный патернализм. «Патернализм был более сильной или более важной частью жизни рабов на границе» $[1, \mathrm{p} .61-62]$. Кроме того, автор поясняет почему беглые рабы с южных штатов стороной обходили Техас. По его мнению, Центральный Техас в предвоенное время представлял поселенцев трех культур: иммигрантов Британского соответствия, где было отменено рабство; мексиканцев и коренных народов США - индейцев. В связи с этим беглым рабам там было тяжелее устроиться, чем в северных штатах. У. Карригэн считает исторические исследования, в которых утверждается, что рабы в южных штатах перед Гражданской войной были довольны своим положением, несостоятельными. Он пишет: «Пограничная особенность рабовладения, изменяет наше понимание о беглых рабах в Соединенных Штатах и бросает вызов историям южан, которые указывают на снижение сопротивления рабов на довоенном Юге» [1, p. 42].

Эти же аргументы подтверждаются в эссе Джо Брекнера «Переход от раба-гонча- ра к свободному гончару. Гончарные мастерские Уилсона графства Гуадалупе» [1, p. 7074]. На основе раскопок глиняной посуды, проведенных в 1981 г., автор утверждает, что в Центральном Техасе рабы не только были заняты в сельском хозяйстве и скотоводстве, но и в гончарном производстве. «История гончарных мастерских Капоте начинается в 1856 году, когда преподобный Джон М. Уилсон, пресвитерианский священник прибыл в окрестности Сегуина со своей семьей и примерно двадцатью черными рабами» $[1$, p. 70]. На протяжении 12 лет гончарное производство процветало, особенно после того как рабы стали свободными, а фирма «Дж. Уилсон и К» стала известной и уважаемой в южных штатах. Но, как считает автор, «Успехи, достигнутые чернокожими в первые дни Реконструкции были быстро сведены на нет проявлением расизма (со стороны американского общества. -И. С.), а также недостаточным использованием власти и интереса со стороны Бюро по делам освобожденных рабов» [1, p. 72].

Направление исследований по политической истории можно наблюдать в эссе Дональда Дж. Нимена «Политическая власть негров и уголовное судопроизводство округа Вашингтон, Техас, 1868-1884» [1, p. 75-107]. Как указывает автор, после Гражданской войны афроамериканцы в Техасе активно участвовали в политической жизни, оказывая поддержку Республиканской партии, которой они были обязаны своим освобождением из рабства. Они регистрировались в качестве избирателей, вступали в члены политических клубов, посещали политические встречи и активно голосовали на выборах.

Д. Нимен считает, что большинство американских историков преуменьшают значение избирательного бюллетеня, утверждая, что политические права, предоставленные обнищавшим, экономически зависимым свободолюбивым людям, были недостаточны для защиты их свободы. «Отказавшись от голосования по избирательному бюллетеню, неудивительно, что ученые пренебрегли систематическим изучением того, как черные использовали свои политические права» [1, p. 74-75].

Конечно, пишет далее автор, «эта политическая власть негритянского населения была недолгой и, в конечном счете, они поте- 
ряли свое влияние на государственную политику» [1, p. 75]. При этом он продолжает: «Мы должны изучить усилия черных использовать политическую власть для улучшения своей жизни и расширения своей свободы. И мы должны исследовать пути, в которых предоставление избирательных прав повлияло на исход постэмансипационной борьбы между черными и их бывшими владельцами» [1, p. 75].

В силу того что негритянское население округа Вашингтон в конце Гражданской войны составляло $52 \%$, местные чернокожие лидеры и небольшое количество белых юнионистов присоединились к недавним мигрантам с севера и нескольким бывшим вигам, которые ранее поддерживали Конфедерацию, чтобы организовать партию - Лигу Союза.

Политическими инструментами, которые использовали вольноотпущенники, были:

- политический союз с немецкими иммигрантами, которые враждебно относились к плантаторской политической элите;

- оказание электоральной поддержки тем республиканским кандидатам, которые в большей степени откликались на защиту их прав;

- Республиканский районный кокус Republican Precinct Caucus (далее - RPC), заменивший Лигу Союза.

$\mathrm{RPC}$ контролировался в течение 1870-х гг. темнокожими лидерами, и это дало возможность в течение указанного периода увеличить количество темнокожих кандидатов и чиновников. Хотя, как признает Д. Нимен «ни один чернокожий не получил от партии выдвижение на влиятельные посты в качестве шери$\phi а$, окружного судьи или судьи графства. Тем не менее они не были исключены из других государственных должностей. Они получили большинство избирательных мест от Республиканской партии в легислатуре штата в течение 1870-х гг.» [1, p. 77].

Автор также считает, что политический успех республиканцев оказывал прямое влияние на систему уголовного судопроизводства округа Вашингтон, где одна четвертая часть присяжных была из числа темнокожих. В больших жюри было до 15 \% темнокожих, а в малых - до $40 \%$ в течение 1870 -х годов. Причем социальный статус был важнее расы в определении поведения Большого жюри чернокожих. «Если большинство черных Большо- го жюри были проповедниками, учителями и ремесленниками, которые владели скромной собственностью, они, возможно, менее сочувствовали малоимущим черным рабочим, обвиняемым в воровстве» $[1$, p. 83$]$.

Автор также отмечает, что участие темнокожих в судопроизводстве резко снизилось после того, как Закон о присяжных 1876 г., который предусматривал, что присяжные должны быть грамотными, «резко изменил социально-экономический профиль Большого жюри чернокожих» [1, p. 84]. Далее Д. Нимен в эссе исследует усиление политического давления белого населения против темнокожих в 1880-1890 гг., но это выходит за рамки нашего исследования.

Отдельным направлением являются исследования антропологической истории. Так, Робертом Д. Хиксом была опубликована монография «Медицина Гражданской войны: дневник хирурга» [4]. Она состоит из двух частей: в первой части пять глав - это тексты дневника Джеймса Фултона, двадцатидевятилетнего хирурга, который в первой половине 1862 г. поступил добровольцем в полк армии северян, где служил до весны 1864 г. и вел ежедневные (иногда с перерывами) дневниковые записи и комментарии. В этих главах сохранена орфография и пунктуация Дж. Фултона. Три главы составляют редакторские подразделы с замечаниями. Вторая часть содержит шесть академических эссе, авторы которых хорошо знают этот исторический период времени и поэтому рассматривают Фултона в его собственном времени и обстоятельствах, «избегая исторических сравнений между медицинским миром Фултона и нашим» [4, p. 3].

Авторов монографии попросили изучить дневник и написать эссе в ответ на конкретные вопросы, которые намеревался исследовать Фултон как актор в пределах своей военной медицинской культуры. Как указал в монографии Р. Хикс, дневник Дж. Фултона стал известен историкам случайно в 2012 году. Из монографии мы узнаем, что последний участвовал в известных военных кампаниях: в Оверлендской кампании, или Наземной кампании (Overland Campaign), в битве в Глуши (Battle of the Wilderness), в битве при Геттисберге (Battle of Gettysburg). 
Несмотря на то что при капитуляции в Геттисберге конфедераты изъяли у хирурга медицинские инструменты, дневник удалось сохранить. Как пишет Р. Хикс, «создавая книгу о Дж. Фултоне как антропологическую историю, дневник может быть прочитан как расшифрованная устная история о медицинской субкультуре армии Союза» [4, p. 3].

Кроме того, по мнению Р. Хикса, повышенный интерес к дневникам проявляется потому, что большинство дневников и частной корреспонденции не подлежали цензуре, что усиливает к ним научный интерес. Другие исследователи читают эти самые отчеты, чтобы получить представление о мотивации, реакции на события и отношения с другими солдатами, гражданскими лицами и их семьями, чтобы реконструировать социальную среду военного времени.

Далее в монографии Р. Хикс утверждает, что дневники, корреспонденция и отчеты военных врачей представляют собой поджанр антропологической литературы и убедительно это доказывает.

Продолжением в исследовании антропологической истории можно считать монографию Джеймса Дж. Брумолла «Частные сообщества конфедератов: эмоциональные миры южных мужчин как граждан и солдат» [2]. В этой книге автор обращается к частным (письмам, дневникам, воспоминаниям, семейным архивам, документам завещаний) и общественным (газетам, журналам, донесениям) источникам, чтобы через выраженные в них чувства участников Гражданской войны, лучше понять конфедератов как проигравшую сторону, которой предстояло жить в новом союзном государстве. Причем материалы первоисточников используются практически без редактирования, чтобы «сохранить целостность оригинальных слов и фраз; sic (авторская мета. - И. С.) не используется без крайней необходимости» [2, p. 8].

Шесть глав монографии включают период с 1840 по 1870 г., представляющий частную жизнь рабовладельцев и не владевших рабами людей южных штатов, характерные черты, традиции и ценности которых позволяли абсолютно осознанно и комфортно воспринимать существовавший порядок и защищать его. В работе Дж. Брумолла исследуются мысли и чувства граждан-южан как в состоянии войны, так и последующего мира. На войне они искренне верили в свою победу, потому что считали, что борются за правое дело. Став побежденными, они потеряли основу в своей жизни. По мнению автора, это объясняется тем, что «люди, которые когдато определяли свою жизнь по древнему кодексу чести и были мобилизованы в армии, веря в правоту своего дела, теперь подвергались неуверенности в себе, позору и покорности» [2, р. 9].

Но при этом, как считает Дж. Брумолл, палитра чувств побежденных южан была разнообразнее, чем у победителей, несмотря на то что в ней превалировали тревога (anxiety), депрессия (depression), изоляция (isolation), меланхолия (melancholy) и тоска (blues).

За время войны ими были созданы новые отношения, проявившиеся в том, как южане взаимодействовали и воспринимали друг друга, они «характеризовались новыми уровнями эмоционального раскрытия, природной близостью и чувством товарищества, которые перенеслись в послевоенную эпоху» [2, р. 5].

Автор считает, что лишение некоторых бывших конфедератов избирательных прав и одновременное предоставление прав афроамериканцам вызвало ожесточенное оскорбление чести белых. В связи с этим по всему югу белые южане расширяли сегрегацию как меру в ответ на послевоенный федеральный порядок. Демонтаж этого порядка происходил через насилие и террор, которые служили эффективными инструментами. Ку-клукс-клан стал самым ярким примером насилия белых южан. «Отдельные акты Ку-клукс-клана были связаны с эмоциональным выражением южан, выросшим из расизма и поражения» [2, p. 11].

По замечанию Дж. Брумолла, если война изменила северян незначительно, то «Гражданская война изменила южан, изменила их семейные и личные отношения, расширила их возможности самовыражения» [2, p. 154]. И многие из них, соблюдая приверженность к восстановлению довоенного социального порядка, направили свои «необузданные эмоции и реакционные политические возможности в рамки дополнительного насилия против федерального правительства и афроамериканцев» [2, р. 155]. 
Ку-клукс-клан возник как проявление нереализованных возможностей ветеранов в новом общественном порядке, которым управляло уже новое поколение, в большинстве своем не участвовавшее в прошедшей войне. Это новое поколение не смогло преодолеть наследство от прошлого рабовладения, оставив вопросы расизма неразрешимыми на многие десятилетия вперед.

Следующее направление в исследованиях этой тематики - культурная история в контексте того, как последствия Гражданской войны и Реконструкции влияли и влияют на политическую и социальную культуру последующих поколений. Подобное исследование содержится в коллективной монографии «Места сражения Гражданской войны: взгляд на конфликт глазами ведущих историков» под редакцией Гари В. Галлахера и Дж. Мэтью Галлмена [5]. Редакторы в предисловии отмечают, что «места памяти подвергаются обсуждению их политического значения. Статуи и другие памятники рассказывают нам о прошлом, даже когда их постоянное присутствие побуждает к продолжающимся разговорам» $[5$, p. 1$]$.

Монография состоит из 26 эссе, 25 из которых написаны профессиональными историками, последнее - фотографом, который снял 30 примечательных мест, выбранных по заданию редакторов их друзьями-историками, научные интересы которых связаны с Гражданской войной, с одним условием, что указанное место должно стать единственным и быть иллюстрацией к их эссе. Как подчеркивают редакторы: «Мы намеренно выбрали не исторические образы, а скорее иллюстрации, которые помогли бы читателю увидеть то, что каждый автор описывает сегодня ....Мы ищем места, где происходили исторические события, возможно, чтобы лучше понять, что там произошло, или, возможно, как своего рода дань уважения тому, что было потеряно» [5, p. 1-2].

В монографии из 30 размещенных авторских фотографий фотографа Г.В. Галлахера 11 являются уникальными, потому что их невозможно найти ни в одном туристическом издании, а эти места до сих пор сохраняются и отражают собой (в полной или неполной мере) события более чем полувековой давности.
Редакторы считают, что изучать Гражданскую войну следует в том числе и через «места памяти», потому что: во-первых, они являются символами, выражающими ценности и убеждения людей ряда поколений; вовторых, они «становятся местами патриотических парадов или политических съездов или других событий», отражающих текущие политические события; в-третьих, они порой разрешают противоречия, возникшие в обществе; в-четвертых, они «подвергаются непрерывным дебатам о политическом значении» прошлых и нынешних событий; в-пятых, они определяют политическую культуру и национальные традиции [5, p. 2]. Все это предопределяет значение этой монографии не только для широкого круга людей, но также и для специалистов, знакомых не понаслышке с историей Гражданской войны.

К исследованию культурной истории следует отнести также монографию Джелани Ману-Говон Фейворс «Укрытие во время шторма: как колледжи для черных способствовали студенческой активности» [7], в которой прослеживается борьба афроамериканцев за гражданские права через получение высшего образования и ведение активной политической работы на протяжении 150 -летней истории после отмены рабства в США. По теме нашего обзора нас заинтересовали первые две главы исследования периода Гражданской войны и Реконструкции.

В начале введения к своей книге автор указывает на важность политической борьбы афроамериканцев даже во второй половине $\mathrm{XX}$ в. через получение университетского образования. В 1960 г. в США был создан Студенческий Ненасильственный Координационный Комитет (Student Nonviolent Coordinating Committee - SNCC), который добивался повсеместного приема на обучение в колледжах и университетах афроамериканцев. Комитет считал, что «колледжи, принимающие афроамериканцев формируют жизненный переломный момент для более широкой борьбы за освобождение» [7, р. 2]. Начало этому движению, как это ни покажется странным, положил аболиционист Джон Браун, который 16 октября 1859 г. в г. Харперс-Ферри с 18 афроамериканцами решил захватить арсенал, чтобы положить конец институту рабства. 
После вмешательства властей все были схвачены, а Браун повешен 2 декабря 1859 года. Суд над аболиционистом привлек внимание к проблеме рабства. После Гражданской войны баптистские миссионеры из Новой Англии приобрели несколько зданий в городе и основали колледж Сторер. Основной целью учреждения было давать образование бывшим рабам, однако оно было открыто для студентов любой национальности и пола (непонятно все же, причем здесь Джон Браун?).

Результаты. Проанализировав новые американские исследования по теме Гражданской войны и Реконструкции, опубликованные в 2019 г., можно сделать следующие общие и частные выводы:

1. Для американских историков данная тематика исследований является важной и актуальной, потому что в обществе существует на нее постоянный спрос. На наш взгляд, это связано с глубокой психоцивизационной травмой, полученной во время этого исторического периода американским народом. Решив военным путем воссоединить государство и выполнив эту задачу, американское общество в силу его характерных черт, традиций и политической культуры не смогло полностью решить вторую задачу - освободить чернокожих американцев от сегрегации, чтобы иметь им возможность пользоваться всеми гражданскими, экономическими и политическими правами.

2. События Гражданской войны и Реконструкции разорвали в американской истории последовательность культурологических мифов о богоизбранном предназначении американской нации для построения «града на холме» и ее исключительности. И как бы отдельные авторы ни пытались находить все новые и новые примеры взаимодействия афроамериканцев и белых во время Гражданской войны, результатами ее смогли воспользоваться в полной мере только белые американцы. Отмена же рабства была заменена вековой сегрегацией.

3. В целом сегодняшние исследования не только уточняют отдельные события и факты военной истории, но они также указывают на то, что наступление сегрегации было обусловлено отсутствием действенных мер социально-экономического порядка со стороны государства по отношению к освобожденным от рабства афроамериканцам. Правительство не решило для них вопросы жилья, занятости и образования, создав еще большую зависимость в условиях свободного капиталистического рынка.

4. В качестве частных выводов по исследованию военной истории следует признать, что американский историк Л. Даниэль в своем исследовании уточнил влияние многочисленных факторов на низкую боеспособность армии Теннесси, приведших к ее поражению. Историк Д. Сикинет, исследовав многочисленные примеры сдачи и капитуляций с обеих сторон во время Гражданской войны, пришел к выводу, что сам факт многочисленных капитуляций - явление, которое не имело признаков позора или бесчестья для белых участников, тогда как для афроамериканцев случай попадания в плен к конфедератам грозил обращением в рабство, пытками или казнью. Отдельно следует сказать о коллективной монографии «Гражданская война на РиоГранде», в которой авторы соединили события Мексиканской и Гражданской войны, как имеющие отношение к одному поколению людей и одному мультикультурному обществу, разделившемуся по вопросам не столько рабства, сколько признания большей независимости для пограничного сообщества. Работа Ф. Джерарда, состоящая из многочисленных эссе, уточняет события военной истории штата Северная Каролина.

5. Исследование политической и экономической истории времен Гражданской войны и Реконструкции, представленное в монографии Дж.П. Рейди, устанавливает особый подход к факту отмены рабства и эмансипации в период Гражданской войны. Автор утверждает, что отмена рабства представляла собой длительный политический процесс, а не разовый законодательный акт. Причем углубление процесса эмансипации сопровождалось в большей степени действиями афроамериканцев, стремившихся получить полную свободу. В то же время введенные автором категории (время, пространство и дом как местожительство) только затеняют объяснение «иллюзий эмансипации». Другим примером исследования экономической и культурной истории является монография Э. Хита, в 
которой автором совершенно справедливо делается вывод о том, что промышленная революция и урбанизация американских городов середины XIX в. стали объективными, но косвенными предпосылками Гражданской войны.

6. Одним из важных направлений исследования Гражданской войны являются истории повседневности. Такие истории содержатся в монографии Дж.Г. Мендеза. Все они найдены в Национальном архиве США и представляют новый взгляд как на положение семей афроамериканцев, чьи отцы участвовали в боевых действиях, так и на степень их унижения в армиях Севера и Юга. К этому же направлению исследований относится коллективная монография под редакцией Б.А. Гласрада и Д.М. Лайлс. Все собранные эссе объединены одним посылом, состоящим в изложении особенностей рабства в пограничном районе, каким на то время являлся штат Техас. Эти эссе опровергают многие устоявшиеся представления о состоянии рабства в пограничном районе.

7. Отдельным направлением являются исследования по антропологической истории времен Гражданской войны. В монографии Р.Д. Хикса исследуется дневник военного хирурга, который не имел редакторской или цензурной правки и позволяет из «первых рук» получить устную историю армии Союза. Продолжением в исследовании этого направления можно считать монографию Дж.Дж. Брумолла, где автор обращается к частным и общественным источникам, чтобы через выраженные в них чувства участников Гражданской войны - конфедератов - понять сложность принятия нового послевоенного порядка на своей земле.

8. Культурная история представлена коллективной монографией под редакцией Г.В. Галлахера и Дж.М. Галлмена. По замыслу авторов, в ней представлены не исторические образы, а иллюстрации, представляющие «исторические следы» прошлого, которые находятся сегодня среди нас, и тем самым влияют на нашу историческую память. Следует обратить внимание на то, что американцы очень бережно относятся к своему историческому прошлому и людям, независимо на какой (проигравшей или выигравшей) стороне они находились. К этому же направлению исследований относится монография Дж.М-Г. Фейворса, в которой прослеживается борьба афроамериканцев за гражданские права через получение высшего образования и ведение активной политической работы.

\section{СПИСОК ЛИТЕРА ТУРЫ}

1. African Americans in Central Texas History: From Slavery to Civil Rights / ed. by B. A. Glasrud, D. M. Liles. - Texas : Texas A\&M University Press, 2019. $-328 \mathrm{p}$.

2. Broomall, J. J. Private Confederacies: The Emotional Worlds of Southern Men As Citizens and Soldiers / J. J. Broomall. - Chapel Hill : University of North Carolina Press, 2019. - 240 p.

3. Campbell, R. B. An Empire for Slavery: The Peculiar Institution in Texas, 1821-1865 / R. B. Campbell. - Baton Rouge : Louisiana State University Press, 1989. $-344 \mathrm{p}$.

4. Civil War Medicine: A Surgeon's Diary / ed. by R. D. Hicks. - Bloomington : Indiana University Press, 2019. -408 p.

5. Civil War Places: Seeing the Conflict Through the Eyes of Its Leading Historians / ed. by G. W. Gallagher, J. M. Gallman. - Chapel Hill : The University of North Carolina Press, 2019. - 216 p.

6. Daniel, L. J. Conquered: Why the Army of the Tennessee Failed / L. J. Daniel. - Chapel Hill : University of North Carolina Press, 2019. - 456 p.

7. Favors, J. M-G. Shelter in a Time of Storm: How Black Colleges Fostered Student Activism / J. M-G. Favors. - Chapel Hill : University of North Carolina Press, 2019. -368 p.

8. Gerard, Ph. The Last Battleground: The Civil War Comes to North Carolina / Ph. Gerard. - Chapel Hill : University of North Carolina Press, 2019. - 362 p.

9. Heath, A. In Union There is Strength: Philadelphia in the Age of Urban Consolidation / A. Heath. Philadelphia : University of Pennsylvania Press, 2019. $296 \mathrm{p}$.

10. Mendez, J. A Great Sacrifice: Northern Black Soldiers, Their Families, and the Experience of Civil War / J. A. Mendez. - N. Y. : Fordham University Press, 2019. $-304 \mathrm{p}$.

11. Questia's Library. - Electronic text data. Mode of access: https://www.questia.com (date of access: 25.12 .2019 ). - Title from screen.

12. Reidy, J. P. Illusions of Emancipation: The Pursuit of Freedom and Equality in the Twilight of Slavery/J. P. Reidy. - Chapel Hill : University of North Carolina Press, 2019. $-520 \mathrm{p}$.

13. Silkenat, D. Raising the White Flag: How Surrender Defined the American Civil War / D. Silkenat.- 
Chapel Hill : University of North Carolina Press, 2019.$368 \mathrm{p}$.

14. The Civil War on the Rio Grande, 1846-1876/ed. byR. Bacha-Garza, Ch. L. Miller, R. K. Skowronek.-Texas : Texas A\&M University Press, 2019. - 326 p.

15. West, E. The Last Indian War: The Nez Perce Story/ E. West. - N. Y. : Oxford University Press, 2009.$432 p$.

16. Wiseman, N. In Search of Canadian Political Culture / N. Wiseman. - Vancouver: University of British Columbia, 2007. -346 p.

\section{REFERENCES}

1. Glasrud B.A., Liles D.M., eds. African Americans in Central Texas History: From Slavery to Civil Rights. Texas, Texas A\&M University Press, 2019.328 p.

2. Broomall J.J. Private Confederacies: The Emotional Worlds of Southern Men as Citizens and Soldiers. Chapel Hill, University of North Carolina Press, 2019. 240 p.

3. Campbell R.B. An Empire for Slavery: The Peculiar Institution in Texas, 1821-1865. Baton Rouge, Louisiana State University Press, 1989. 344 p.

4. Hicks R.D., ed. Civil War Medicine: A Surgeons Diary. Bloomington, Indiana University Press, 2019. $408 \mathrm{p}$.

5. Gallagher G.W., Gallman J.M., eds. Civil War Places: Seeing the Conflict Through the Eyes of Its Leading Historians. Chapel Hill, The University of North Carolina Press, 2019. 216 p.
6. Daniel L.J. Conquered: Why the Army of the Tennessee Failed. Chapel Hill, University of North Carolina Press, 2019. 456 p.

7. Favors J.M-G. Shelter in a Time of Storm: How Black Colleges Fostered Student Activism. Chapel Hill, University of North Carolina Press, 2019. 368 p.

8. Gerard Ph. The Last Battleground: The Civil War Comes to North Carolina. Chapel Hill, University of North Carolina Press, 2019. 362 p.

9. Heath A. In Union There Is Strength: Philadelphia in the Age of Urban Consolidation. Philadelphia, University of Pennsylvania Press, 2019. 296 p.

10. Mendez J. A Great Sacrifice: Northern Black Soldiers, Their Families, and the Experience of Civil War. New York, Fordham University Press, 2019. 304 p.

11. Questias Library. URL: https://www.questia. com (accessed 25 December 2019).

12. Reidy J.P. Illusions of Emancipation: The Pursuit of Freedom and Equality in the Twilight of Slavery. Chapel Hill, University of North Carolina Press, 2019. 520 p.

13. Silkenat D. Raising the White Flag: How Surrender Defined the American Civil War. Chapel Hill, University of North Carolina Press, 2019. 368 p.

14. Bacha-Garza R., Miller Ch.L., Skowronek R.K., eds. The Civil War on the Rio Grande, 1846-1876. Texas, Texas A\&M University Press, 2019. 326 p.

15. West E. The Last Indian War: The Nez Perce Story. New York, Oxford University Press, 2009. 432 p.

16. Wiseman N. In Search of Canadian Political Culture. Vancouver, University of British Columbia, 2007.346 p.

\section{Information About the Author}

Ilya A. Sokov, Doctor of Sciences (History), Associate Professor, Department of International Relations, Political Science and Area Studies, Volgograd State University, Prosp. Universitetsky, 100, 400062 Volgograd, Russian Federation, sokov@volsu.ru, https://orcid.org/0000-0002-7146-7340

\section{Информация об авторе}

Илья Анатольевич Соков, доктор исторических наук, доцент кафедры международных отношений, политологии и регионоведения, Волгоградский государственный университет, просп. Университетский, 100, 400062 г. Волгоград, Российская Федерация, sokov@volsu.ru, https://orcid.org/0000-0002-7146-7340 